\title{
Analisis Limbah Kelapa Sawit Sebagai Bahan Bakar Boiler dengan Menggunakan Variasi Campuran Antara Fiber dan Cangkang Buah Sawit
}

\author{
Jatmiko Edi Siswanto \\ Program Studi, Teknik Mesin, Sekolah Tinggi Teknologi Nasional (STITEKNAS) \\ Jl. Pattimura No. 100 Kota Jambi, Indonesia \\ Correspondence email: jatmikoedis@gmail.com
}

\begin{abstract}
Abstrak. Pertumbuhan industry pengelolaan minyak sawit di jambi yang berdampak pada makin besarnya libah pengelolaan kelapa sawit diantanya adalah Fiber dan Cangkang. Setiap pengolahan 1 ton TBS menghasilkan $120 \mathrm{~kg}$ fiber dan menghasilkan $50 \mathrm{~kg}$ Cangkang. dimana kedua limbah tersebut memunyai nilai kalor yang tinggi dan ribuan ton TBS yang diolah di Jambi setiap bulannya. Pada analisis ini akan menganalisa komposisi pembakaran menggunakan fiber dan cangkang untuk mendapat kan nilai kalor tertinggi pada Boiler, dimana Komposisi yang dianalisa adalah perbandingan Fiber $100 \%$, Fiber $75 \%$ Cangkang $25 \%$, Fiber $50 \%$ Cangkang $50 \%$, Fiber $25 \%$ Cangkang $75 \%$, Cangkang $100 \%$. Hasil analisa penelitian Nilai kalor variasi komposisi fiber dan cangkang berkisar antara 14978,053 kJ/kg sampai dengan 15463,083 kJ/kg. Dengan nilai kalor tertinggi adalah komposisi fiber $100 \%(15463,083 \mathrm{~kJ} / \mathrm{kg})$, dan nilai kalor terendah adalah komposisi cangkang $100 \%$. (14978,053 kJ/kg). Komposisi yang memberikan keuntungan tertinggi adalah komposisi fiber $100 \%$. Dengan rincian nilai kadar air, kebutuhan udara, gas asap yang rendah, dan juga menghasilkan nilai kalor yang tinggi.
\end{abstract}

Kata kunci: Limbah Sawit, Komposisi, Nilai kalor.

Abstract. The growth of the palm oil management industry in Jambi which has an impact on the increasing size of palm oil management holidays include Fiber and Shells. Each processing of 1 ton of FFB produces $120 \mathrm{~kg}$ of fiber and produces $50 \mathrm{~kg}$ of shells. Where the two wastes have a high calorific value and thousands of tons of FFB are processed in Jambi every month. In this analysis will analyze the composition of combustion using fiber and shell to get the highest calorific value on the Boiler, where the composition analyzed is the ratio of 100\% Fiber, 75\% Fiber 25\% Shell, 50\% Fiber 50\% Shell, 25\% Fiber 75\% Shell 100\% shell. The results of research analysis The heating value of fiber and shell composition variations ranged from $14978,053 \mathrm{~kJ} / \mathrm{kg}$ to $15463,083 \mathrm{~kJ} / \mathrm{kg}$. With the highest heating value is $100 \%$ fiber composition $(15463,083 \mathrm{~kJ} / \mathrm{kg}$ ), and the lowest heating value is $100 \%$ shell composition. (14978,053 kJ/kg). The composition that gives the highest profit is the composition of 100\% fiber. With the details of the value of water content, air requirements, low flue gas, and also produces a high heating value.

Keywords: Palm Waste, Composition, Calorific Value.

\section{PENDAHULUAN}

Era globalisasi semakin membuat masyarakat dunia tertantang, karena pesatnya perkembangan dunia yang mengakibatkan antar negara bersaing. Hal ini berdampak pada pemenuhan kebutuhan akan energi atau bahan bakar juga akan semakin bertambah, yang mana dunia industri merupakan salah satu pengkonsumsi energi atau bahan bakar yang cukup besar. Faktor tersebut banyak berpengaruh terhadap kecenderungan ekonomis, sehingga harga bahan bakar semakin meningkat. Semakin meningkatnya harga bahan bakar semakin menipis pula ketersediaan bahan bakar

Limbah pabrik kelapa sawit yang berupa fiber dan cangkang dapat dimanfaatkan untuk bahan bakar boiler sebagai penghasil uap yang digunakan untuk penggerak turbin pembangkit tenaga listrik, juga sumber uap digunakan untuk proses pengolahan dan perebusan (Parinduri, 2016).

Limbah fiber dan cangkang sawit dapat dimanfaatkan secara optimal untuk peningkatan efisiensi boiler (Djokosetyarjo, 2003), di mana perbandingan pemakaian fiber dan cangkang yang tempat akan mendapatkan pembakaran yang sempurna di dalam boiler.

Fiber

Fiber adalah limbah sawit yang dihasilkan dari hasil pengolahan pemerasan buah sawit pada saat proses kempa (press) yang berbentuk pendek seperti benang dan bewarna kuning kecoklatan. Setiap pengolahan 1 ton TBS menghasilkan $120 \mathrm{~kg}$ atau $12 \%$ dari hasil pengolahan per ton. Fiber bisa digunakan sebagai sumber bahan bakar untuk boiler dan mempunyai nilai kalor sekitar $2637 \quad \mathrm{kkal} / \mathrm{kg}-3998 \quad \mathrm{kkal} / \mathrm{kg}$. (Angky Puspawan, 2016) telah melakukan kajian tentang nilai kalor, didapatkan nilai kalor fiber sebesar $3872 \mathrm{kkal} / \mathrm{kg}$. (Harris, 2013) telah melakukan studi pemanfaatan limbah padat dari perkebunan kelapa sawit didapatkan nilai kalor fiber sebesar $3500 \mathrm{kkal} / \mathrm{kg}$ dan (Warman, 2014) dalam kajiannya tentang studi kelayakan ekonomis PLTU berbahan bakar fiber dan cangkang mendapatkan nilai kalor fiber sebesar $2770 \mathrm{kkal} / \mathrm{kg}$. Fiber kelapa sawit dapat dilihat pada gambar 1. 
Jatmiko Edi Siswanto, Analisis Limbah Kelapa Sawit Sebagai Bahan Bakar Boiler dengan Menggunakan Variasi Campuran Antara Fiber dan Cangkang Buah Sawit

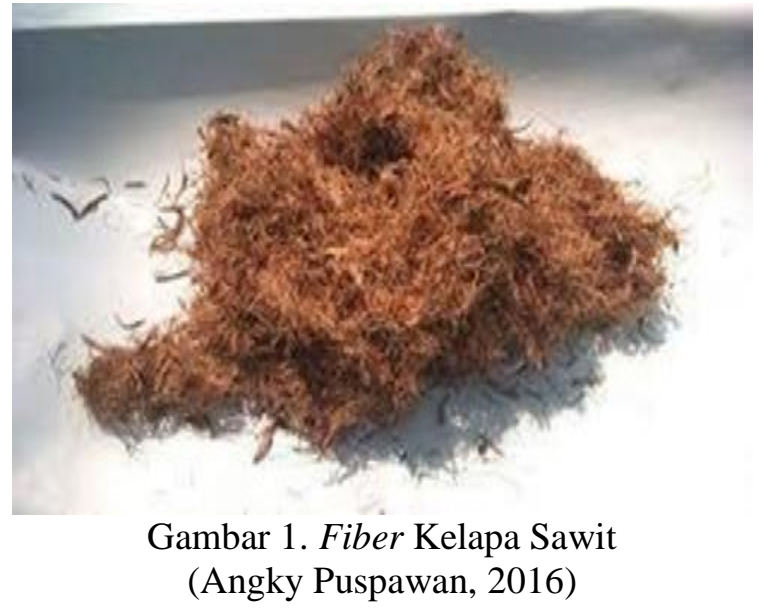

Cangkang

Cangkang merupakan limbah yang dihasilkan dari proses pemrosesan kernel inti sawit dengan bentuk seperti tempurung kelapa namun berbentuk kecil. Setiap pengolahan 1 ton TBS menghasilkan $50 \mathrm{~kg}$ atau $5 \%$ dari hasil pengolahan per ton dan cangkang mempunyai nilai kalor $3500 \mathrm{kkal} / \mathrm{kg}-4100 \mathrm{kkal} / \mathrm{kg}$. (Angky Puspawan, 2016) Telah melakukan kajian tentang analisa nilai kalor cangkang kelapa sawit didapatkan nilai kalor 4580 kkal/kg. (Harris, 2013) telah melakukan studi pemanfaatan limbah padat dari perkebunan kelapa sawit didapatkan nilai kalor cangkang sebesar $4115 \mathrm{kkal} / \mathrm{kg}$ dan (Warman, 2014) dalam kajiannya tentang studi kelayakan ekonomis PLTU berbahan bakar fiber dan cangkang mendapatkan nilai kalor cangkang sebesar $3881 \mathrm{kkal} / \mathrm{kg}$.Cangkang adalah sejenis bahan bakar padat yang berwarna hitam berbentuk seperti batok kelapa dan agak bulat, terdapat pada bagian dalam pada buah kelapa sawit yang diselubungi oleh serabut (Anjani, 2015). Cangkang kelapa sawit dapat dilihat pada gambar 2.

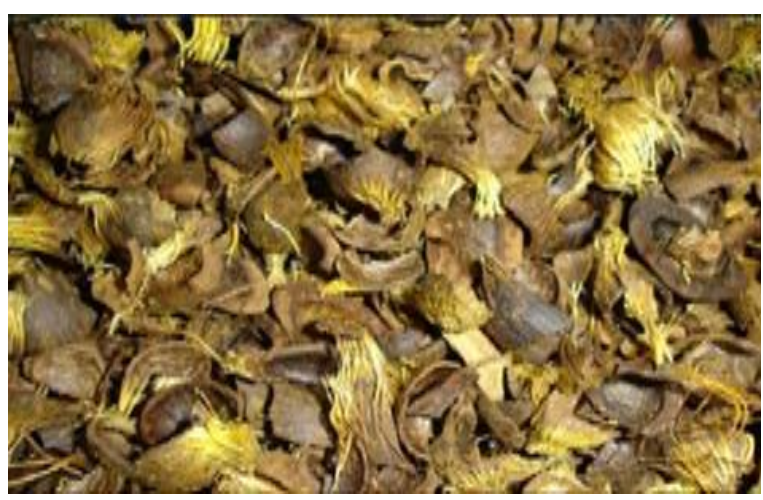

Gambar 2. Cangkang kelapa sawit

(Angky Puspawan, 2016)

\section{Komposisi Bahan Bakar fiber dan Cangkang}

Komposisi dari Unsur-unsur kimia yang terdapat dalam bahan bakar fiber dan cangkang kelapa sawit terdiri dari karbon $(\mathrm{C})$, hidrogen $\left(\mathrm{H}_{2}\right)$, nitrogen $\left(\mathrm{N}_{2}\right)$, oksigen $\left(\mathrm{O}_{2}\right)$, belerang $(\mathrm{S})$, air $\left(\mathrm{H}_{2} \mathrm{O}\right)$, dan abu $(a s h)$.
Komposisi dari unsur-unsur kimia bahan bakar fiber dan cangkang dapat dilihat pada Tabel 1. (Angky Puspawan, 2016)

Tabel 1. Unsur-unsur kimia bahan bakar fiber dan cangkang

\begin{tabular}{ccc}
\hline Nama Unsur & Fiber & Cangkang \\
\hline Karbon $(\mathrm{C})$ & $42,6 \%$ & $50,4 \%$ \\
Hidrogen $(\mathrm{H})$ & $5,2 \%$ & $5,8 \%$ \\
Nitrogen $(\mathrm{N})$ & $0,04 \%$ & $0,05 \%$ \\
Oksigen $\left(\mathrm{O}_{2}\right)$ & $32,1 \%$ & $34,2 \%$ \\
Sulfur $(\mathrm{S})$ & $0,2 \%$ & $0,1 \%$ \\
Air $\left(\mathrm{H}_{2} \mathrm{O}\right)$ & $12,6 \%$ & $16,0 \%$ \\
Abu $($ Ash $)$ & $5,7 \%$ & $4,4 \%$ \\
\hline
\end{tabular}

Untuk menghitung komposisi fiber dan cangkang pada perbandingan 1:3 dapat dihitung dengan rumus berikut:

$\mathrm{C}=\left(\right.$ Komposisi $\left._{1} \times \mathrm{C}_{1}\right)+\left(\right.$ Komposisi $\left._{2} \times \mathrm{C}_{2}\right)$

Keterangan:

$\mathrm{C}=$ Unsur kimia bahan bakar

Komposisi 1 = fiber $100 \%$

$2=$ fiber $75 \%$ dan cangkang $25 \%$

\section{Nilai Kalor (Heating Value)}

Nilai kalor merupakan jumlah energi kalor yang dilepaskan bahan bakar pada waktu terjadinya oksidasi unsur-unsur kimia yang ada pada bahan bakar tersebut. Bahan bakar adalah zat kimia apabila direaksikan dengan Oksigen $\left(\mathrm{O}_{2}\right)$ Akan menghasilkan sejumlah kalor. Bahan bakar dapat berwujud gas, cair, maupun padat. Selain itu, bahan bakar merupakan suatu senyawa yang tersusun atas beberapa unsur seperti karbon (C), Hidrogen $(\mathrm{H})$, Belerang $(\mathrm{S})$, dan Nitrogen $(\mathrm{N})$. Kualitas bahan bakar ditentukan oleh kemampuan bahan bakar untuk menghasilkan energi. Nilai bahan bakar ditentukan oleh komposisi kandungan unsur didalam bahan bakar Ada dua jenis penentuan nilai kalor pada bahan bakar, (Culp, 1996) yaitu:

a. Nilai Kalor Pembakaran Tinggi

Nilai kalor pembakaran tinggi atau juga dikenal dengan istilah High Heating Value (HHV) adalah nilai pembakaran dimana panas pengembunan air dari proses pembakaran ikut diperhitungkan sebagai panas dari proses pembakaran. Dirumuskan dengan:

$$
\mathrm{HHV}=33950 \mathrm{C}+144200\left(\mathrm{H}_{2}-\frac{\mathrm{o}_{2}}{8}\right)+9400 \mathrm{~S} \mathrm{~kJ} / \mathrm{kg}
$$

b. Nilai Kalor Pembakaran Rendah

Nilai kalor pembakaran rendah atau juga dikenal dengan istilah Low Heating Value (LHV) adalah nilai pembakaran dimana panas pengembunan uap air dari hasil pembakaran tidak ikut dihitung sebagai panas dari proses pembakaran. Dirumuskan dengan:

$\mathrm{LHV}=\mathrm{HHV}-2400\left(\mathrm{M}+9 \mathrm{H}_{2}\right) \mathrm{kJ} / \mathrm{kg}$

\section{METODE}

\section{Alat dan Bahan}

Alat 
Jatmiko Edi Siswanto, Analisis Limbah Kelapa Sawit Sebagai Bahan Bakar Boiler dengan Menggunakan Variasi Campuran Antara Fiber dan Cangkang Buah Sawit

\section{Bom Kalorimeter}

Digunakan untuk menentukan nilai kalor tertinggi (high heating value) bahan bakar. Proses pengujian untuk menentukan high heating value bahan bakar dilakukan di laboratorium PT. Lontar Papyrus Pulp and Paper Industry. Pembacaan high heating value (HHV) dapat dilihat dari display monitor. Bom kalorimeter dapat dilihat pada Gambar 3.

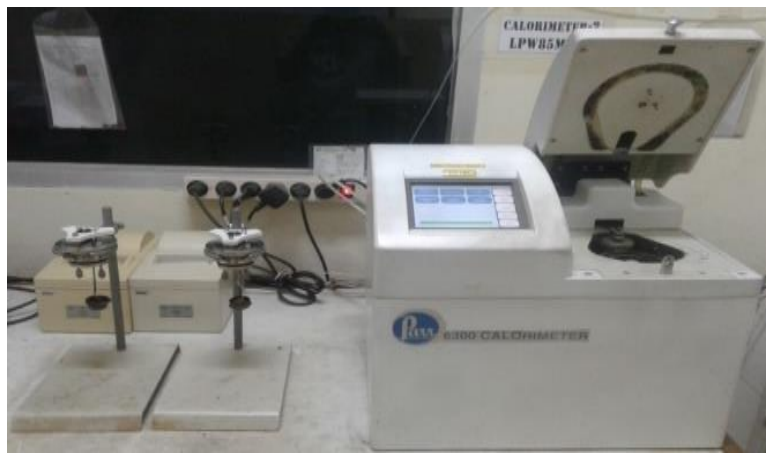

Gambar 3. Bom kalorimeter

Timbangan Digital, digunakan untuk menimbang bahan bakar sampel. Timbangan digital dapat dilihat pada Gambar 4.

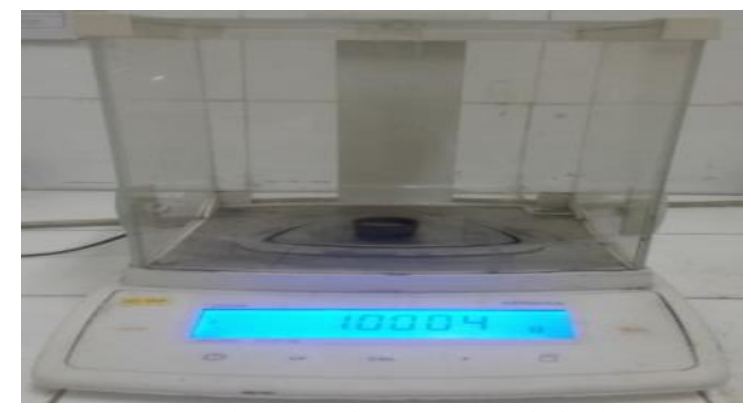

Gambar 4. Timbangan digital

\section{Bahan}

Bahan yang digunakan untuk uji kalorimeter adalah Cangkang dan Fiber sawit dengan variasi komposisi yang telah ditentukan. cangkang dan Fiber kelapa sawit dapat dilihat pada Gambar 5.
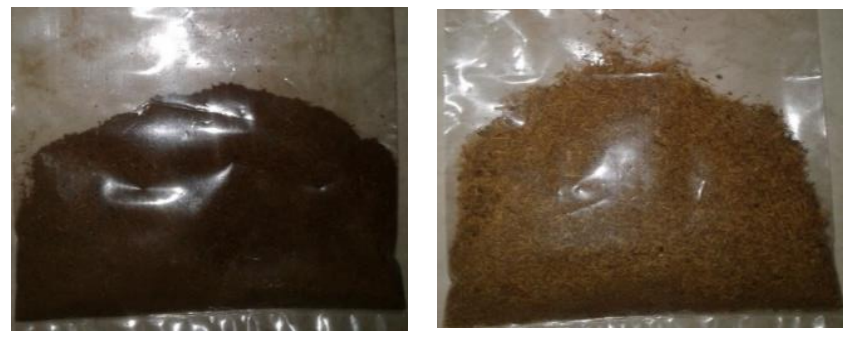

Gambar 5. Cangkang dan fiber kelapa sawit

\section{Prosedur Penelitian}

\section{Persiapan bahan uji}

- Timbang bahan uji minimal 750 gram dan letakkan di dalam nampan.

- Masukkan ke dalam oven pada suhu $40{ }^{\circ} \mathrm{C}$ selama 18 jam dan timbang beratnya.
- Haluskan bahan uji dengan ukuran 325 mesh.

- Lakukan pengujian nilai kalor.

2. Metode percobaan bom kalorimeter

- Hidupkan alat Parr 6200 calorimeter Water recirculation dan printer dengan menekan tombol on.

- Buka tabung oksigen dengan pressure 420-450 psi (30 bar).

- Pilih pada "main menu" tekan "calorimeter operation" display muncul "heater and pump" dan "on" kan untuk menaikkan suhu "Jacket temperature" sampai $30{ }^{\circ} \mathrm{C}$ dengan indikasi warna biru muncul pada layar atau sampai posisi "start" aktif.

- Buka tutup bom kalorimeter dan keluarkan dengan memutar dan menarik bagian atas Bomb.

- Timbang sampel \pm 1 gram dalam crucible dan letakkan dalam

- Baca hasil pengukuran kalori pada monitor di "Gross heat" atau dapat di print dengan menekan perintah "print" analisa telah selesai dilakukan.

3. Metode perhitungan kebutuhan udara dan jumlah gas asap pembakaran

- Mengetahui komposisi dari unsur-unsur kimia bahan bakar

- Menghitung kebutuhan udara teoritis dengan persamaan reaksi-reaksi pembakaran sempurna:

Unsur $\mathrm{C} \quad: \mathrm{C}+\mathrm{O}_{2}=\mathrm{CO}_{2}$

Unsur $\mathrm{H} \quad: 4 \mathrm{H}+\mathrm{O}_{2}=2 \mathrm{H}_{2} \mathrm{O}$

Unsur $\mathrm{S} \quad: \mathrm{S}+\mathrm{O}_{2}=\mathrm{SO}_{2}$

- Setelah diketahui unsur-unsur kimia bahan bakar dan persamaan reaksi di atas dapat dihitung pula jumlah gas asapnya.

4. Metode studi literatur

Studi literatur dilakukan untuk memilih materi-materi pendukung yang sesuai dengan permasalahan yang akan dibahas.

\section{Diagram Alir Penelitian}

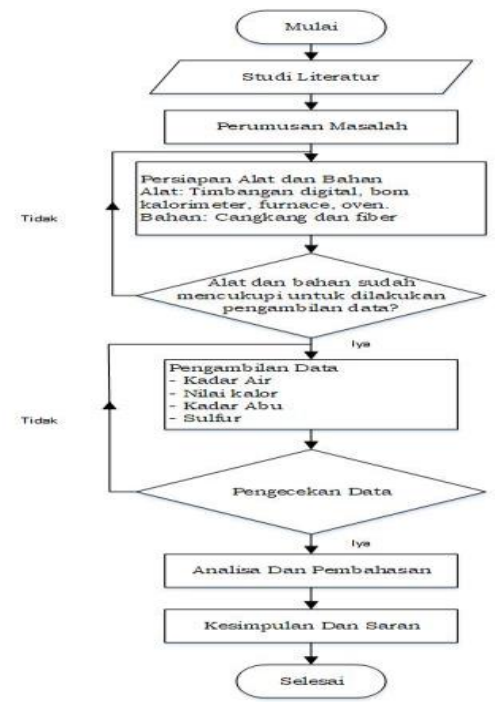

Gambar 6. Diagram alir 
Jatmiko Edi Siswanto, Analisis Limbah Kelapa Sawit Sebagai Bahan Bakar Boiler dengan Menggunakan Variasi Campuran Antara Fiber dan Cangkang Buah Sawit

\section{HASIL DAN PEMBAHASAN \\ Data Hasil Pengujian}

Setelah dilakukan pengujian terhadap variasi komposisi bahan bakar fiber dan cangkang kelapa sawit, didapatkan nilai kalor pembakaran tinggi (HHV) dan unsur-unsur kimia bahan bakar. Data hasil pengujian terhadap variasi komposisi fiber dan cangkang kelapa sawit dapat dilihat pada Tabel 2 dan Tabel 3.

Tabel 2. Nilai kalor dari variasi komposisi (Kom) fiber $(\mathrm{Fb})$ dan cangkang(Ck) kelapa sawit

\begin{tabular}{|c|c|c|c|c|c|}
\hline \multirow{2}{*}{ Komposisi Fb \& Ck (\%) } & \multicolumn{5}{|c|}{ Komposisi Bahan Bakar dan Nilai Kalor (HHV kJ/kg) } \\
\hline & 1 & 2 & 3 & 4 & 5 \\
\hline $100: 0:$ & 16982,472 & 17112,269 & 17015,968 & 16898,732 & 16555,398 \\
\hline $75: 25$ & 16999,220 & 16944,789 & 16706,130 & 16915,480 & 16660,073 \\
\hline $50: 50$ & 16961,537 & 16760,561 & 16781,496 & 16534,463 & 16563,772 \\
\hline $25: 75$ & 16953,163 & 16526,089 & 16521,902 & 16555,398 & 16676,821 \\
\hline $0: 100$ & 16547,024 & 16601,455 & 16907,106 & 16509,341 & 16618,203 \\
\hline Rata-rata & 16888,683 & 16789,033 & 16786,520 & 16682,683 & 16614,853 \\
\hline
\end{tabular}

Tabel 3. Komposisi dari unsur-unsur kimia bahan bakar fiber dan cangkang kelapa sawit

\begin{tabular}{clccc}
\hline No & \multicolumn{1}{c}{ Bahan } & Kadar Air & Kadar Abu & Sulfur \\
\hline 1 & Fiber 100 \% & $12,6 \%$ & $5,7 \%$ & $0,23 \%$ \\
2 & Fiber 75 \% Cangkang 25\% & $13,5 \%$ & $5,4 \%$ & $0,24 \%$ \\
3 & Fiber 50 \% Cangkang 50\% & $14,3 \%$ & $5,1 \%$ & $0,15 \%$ \\
4 & Fiber 25 \% Cangkang 75\% & $15,2 \%$ & $4,7 \%$ & $0,13 \%$ \\
5 & Cangkang 100\% & $16,0 \%$ & $4,4 \%$ & $0,09 \%$ \\
\hline
\end{tabular}

\section{Komposisi Bahan Bakar}

Komposisi dari Unsur-unsur kimia yang terdapat dalam bahan bakar fiber dan cangkang kelapa sawit terdiri dari karbon $(\mathrm{C})$, hidrogen $\left(\mathrm{H}_{2}\right)$, nitrogen $\left(\mathrm{N}_{2}\right)$, oksigen $\left(\mathrm{O}_{2}\right)$, belerang $(\mathrm{S})$, air $\left(\mathrm{H}_{2} \mathrm{O}\right)$, dan abu (ash).

Untuk menghitung komposisi dari unsur-unsur kimia bahan bakar dapat menggunakan rumus berikut: $\mathrm{C}=\left(\right.$ Komposisi $\left._{1} \times \mathrm{C}_{1}\right)+\left(\right.$ Komposisi $\left._{2} \times \mathrm{C}_{2}\right)$

Keterangan:

$\mathrm{C}=$ Unsur kimia bahan bakar

Komposisi $1=$ fiber $100 \%$

$2=$ fiber $75 \%$ dan cangkang $25 \%$

$3=$ fiber $50 \%$ dan cangkang $50 \%$

$4=$ fiber $25 \%$ dan cangkang $75 \%$

$5=$ Cangkang $100 \%$

Maka perhitungan komposisi dari fiber $75 \%$ dan Cangkang $25 \%$ adalah sebagai berikut:

$$
\begin{aligned}
& \mathrm{C}=\left[\frac{75}{100} \times 42,6 \%\right]+\left[\frac{25}{100} \times 50,4 \%\right]=44,6 \% \\
& \mathrm{H}_{2}=\left[\frac{75}{100} \times 5,2 \%\right]+\left[\frac{25}{100} \times 5,8 \%\right]=5,4 \% \\
& \mathrm{~N}_{2}=\left[\frac{75}{100} \times 0,04 \%\right]+\left[\frac{25}{100} \times 0,05 \%\right]=0,04 \% \\
& \mathrm{O}_{2}=\left[\frac{75}{100} \times 32,1 \%\right]+\left[\frac{25}{100} \times 34,2 \%\right]=32,6 \% \\
& \mathrm{~S}=\left[\frac{75}{100} \times 0,2 \%\right]+\left[\frac{25}{100} \times 0,1 \%\right]=0,2 \% \\
& \mathrm{H}_{2} \mathrm{O}=\left[\frac{75}{100} \times 12,6 \%\right]+\left[\frac{25}{100} \times 16,0 \%\right]=13,5 \% \\
& \text { Ash }=\left[\frac{75}{100} \times 5,7 \%\right]+\left[\frac{25}{100} \times 4,4 \%\right]=5,4 \%
\end{aligned}
$$

\begin{tabular}{|c|c|c|c|c|c|}
\hline \multirow{2}{*}{ Unsur } & \multicolumn{5}{|c|}{ Komposisi Bahan Bakar } \\
\hline & 1 & 2 & 3 & 4 & 5 \\
\hline $\mathrm{C}$ & $42,6 \%$ & $44,6 \%$ & $46,5 \%$ & $48,5 \%$ & $50,4 \%$ \\
\hline $\mathrm{H}_{2}$ & $5,2 \%$ & $5,4 \%$ & $5,5 \%$ & $5,7 \%$ & $5,8 \%$ \\
\hline $\mathrm{N}_{2}$ & $0,04 \%$ & $0,04 \%$ & $0,05 \%$ & $0,047 \%$ & $0,05 \%$ \\
\hline $\mathrm{O}_{2}$ & $32,1 \%$ & $32,6 \%$ & $33,2 \%$ & $33,7 \%$ & $34,2 \%$ \\
\hline $\mathrm{S}$ & $0,2 \%$ & $0,2 \%$ & $0,15 \%$ & $0,13 \%$ & $0,1 \%$ \\
\hline $\mathrm{H}_{2} \mathrm{O}$ & $12,6 \%$ & $13,5 \%$ & $14,3 \%$ & $15,2 \%$ & $16,0 \%$ \\
\hline Ash & $5,7 \%$ & $5,4 \%$ & $5,1 \%$ & $4,7 \%$ & $4,4 \%$ \\
\hline
\end{tabular}

Dengan perhitungan yang sama telah didapatkan unsur-unsur kimia dari variasi komposisi lainnya.
Komposisi dari unsur-unsur kimia bahan bakar fiber dan cangkang kelapa sawit dapat dilihat pada Tabel 4.

Tabel 4. Komposisi dari unsur-unsur kimia bahan bakar fiber dan cangkang kelapa sawit.

\section{Perhitungan Data}

Nilai Kalor

Ada dua jenis penentuan nilai kalor pada bahan bakar yaitu nilai kalor pembakaran tinggi (HHV) yang nilainya telah didapatkan pada saat pengujian dengan menggunakan alat uji kalorimeter dan nilai kalor pembakaran rendah (LHV).

Perhitungan nilai kalor pembakaran rendah dilakukan dengan menggunakan rumus sebagai berikut: $\mathrm{LHV}=\mathrm{HHV}-2400\left(\mathrm{M}+9 \mathrm{H}_{2}\right) \mathrm{kJ} / \mathrm{kg}$

Keterangan: $\mathrm{HHV}=$ Nilai kalor pembakaran tinggi

$\mathrm{M}=$ Moisture (Kandungan air dalam bahan bakar)

$\mathrm{H}_{2} \quad$ = Hidrogen dalam bahan bakar

Maka Perhitungann nilai kalor untuk bahan bakar fiber $100 \%$ adalah sebagai berikut:

1. Pengujian I

Diketahui HHV $=16982,472 \mathrm{~kJ} / \mathrm{kg}$

$\mathrm{M}=12,6 \%$

$\mathrm{H}_{2}=5,2 \%$

Nilai kalor pembakaran rendah:

$\mathrm{LHV}=\mathrm{HHV}-2400\left(\mathrm{M}+9 \mathrm{H}_{2}\right) \mathrm{kJ} / \mathrm{kg}$ 
Jatmiko Edi Siswanto, Analisis Limbah Kelapa Sawit Sebagai Bahan Bakar Boiler dengan Menggunakan Variasi Campuran Antara Fiber dan Cangkang Buah Sawit

$\mathrm{LHV}=15556,872 \mathrm{~kJ} / \mathrm{kg}$

2. Pengujian II

Diketahui HHV $=16999,220 \mathrm{~kJ} / \mathrm{kg}$

$\mathrm{M}=13,5 \%$

$\mathrm{H} 2=5,4 \%$

Nilai kalor pembakaran rendah:

$\mathrm{LHV}=\mathrm{HHV}-2400\left(\mathrm{M}+9 \mathrm{H}_{2}\right) \mathrm{kJ} / \mathrm{kg}$

$\mathrm{LHV}=15573,620 \mathrm{~kJ} / \mathrm{kg}$

3. Pengujian III

Diketahui HHV $=16961,537 \mathrm{~kJ} / \mathrm{kg}$

$\mathrm{M}=14,3 \%$

$\mathrm{H} 2=5,5 \%$

Nilai kalor pembakaran rendah:

$\mathrm{LHV}=\mathrm{HHV}-2400\left(\mathrm{M}+9 \mathrm{H}_{2}\right) \mathrm{kJ} / \mathrm{kg}$

$\mathrm{LHV}=15535,937 \mathrm{~kJ} / \mathrm{kg}$

4. Pengujian IV

Diketahui HHV $=16953,163 \mathrm{~kJ} / \mathrm{kg}$

$\mathrm{M}=15,2 \%$

$\mathrm{H} 2=5,7 \%$

Nilai kalor pembakaran rendah:

$\mathrm{LHV}=\mathrm{HHV}-2400\left(\mathrm{M}+9 \mathrm{H}_{2}\right) \mathrm{kJ} / \mathrm{kg}$
“ $15527,563 \mathrm{~kJ} / \mathrm{kg}$

5. Pengujian V

Diketahui HHV $=16547,024 \mathrm{~kJ} / \mathrm{kg}$

$\mathrm{M}=16,0 \%$

$\mathrm{H} 2=5,8 \%$

Nilai kalor pembakaran rendah:

$\mathrm{LHV}=\mathrm{HHV}-2400\left(\mathrm{M}+9 \mathrm{H}_{2}\right) \mathrm{kJ} / \mathrm{kg}$

$\mathrm{LHV}=15121,424 \mathrm{~kJ} / \mathrm{kg}$

Maka nilai rata-rata kalor pembakaran rendah fiber $100 \%$ adalah sebagai berikut :

LHV (Rata-rata) $=\frac{\text { Jumlah nilai }}{\text { Banyaknya pengujian }}$

$=\frac{15556,872+15573,620+15535,937+15527,563+15121,424}{5}$

$=15463,083 \mathrm{~kJ} / \mathrm{kg}$

Dengan perhitungan yang sama telah didapatkan nilai kalor dari variasi komposisi lainnya. Nilai rata-rata dari variasi komposisi fiber dan cangkang kelapa sawit dapat dilihat pada Tabel 5.

Tabel 5. Rekap hasil perhitungan nilai kalor rata-rata dari variasi komposisi fiber dan cangkang kelapa sawit

\begin{tabular}{clcc}
\hline No & \multicolumn{1}{c}{ Bahan } & HHV (kJ/kg) & LHV (kJ/kg) \\
\hline 1 & Fiber 100 \% & 16888,683 & 15463,083 \\
2 & Fiber 75 \% Cangkang 25 \% & 16789,033 & 15298,633 \\
3 & Fiber 50 \% Cangkang 50 \% & 16786,520 & 15255,320 \\
4 & Fiber 25 \% Cangkang 75 \% & 16682,683 & 15086,683 \\
5 & Cangkang 100\% & 16614,853 & 14978,053 \\
\hline
\end{tabular}

\section{Analisis Data}

\section{Nilai Kalor}

Nilai kalor menunjukkan kalor yang berpindah bila hasil pembakaran sempurna. Nilai kalor ditentukan dengan menggunakan standar uji bom kalorimeter menurut standar ASTM D 2015-95.

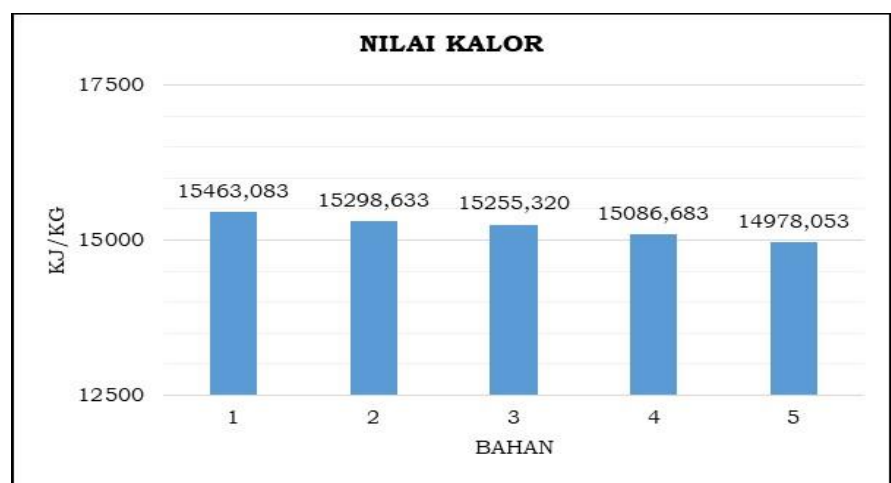

Gambar 7. Nilai kalor dari variasi komposisi bahan bakar fiber dan cangkang kelapa sawit

Dari gambar.7 dapat dilihat nilai kalor dari variasi komposisi bahan bakar fiber dan cangkang kelapa sawit. Bahan 1 komposisi fiber $100 \%$ dengan nilai 15463,083 $\mathrm{kJ} / \mathrm{kg}$, bahan 2 komposisi fiber $75 \%$ dan cangkang $25 \%$ dengan nilai $15298,633 \mathrm{~kJ} / \mathrm{kg}$, bahan 3 komposisi fiber $50 \%$ dan cangkang $50 \%$ dengan nilai $15255,320 \mathrm{~kJ} / \mathrm{kg}$, bahan 4 komposisi fiber $25 \%$ dan cangkang $75 \%$ dengan nilai $15086,683 \mathrm{~kJ} / \mathrm{kg}$, bahan 5 komposisi cangkang $100 \%$ dengan nilai $14978,053 \mathrm{~kJ} / \mathrm{kg}$.

Dari penelitian ini didapatkan bahwa nilai kalor dipengaruhi oleh kadar air dan kadar abu bahan bakar fiber dan cangkang kelapa sawit. Grafik perbandingan kadar air dan kadar abu terhadap nilai kalor dapat dilihat pada Gambar,8 di bawah ini:

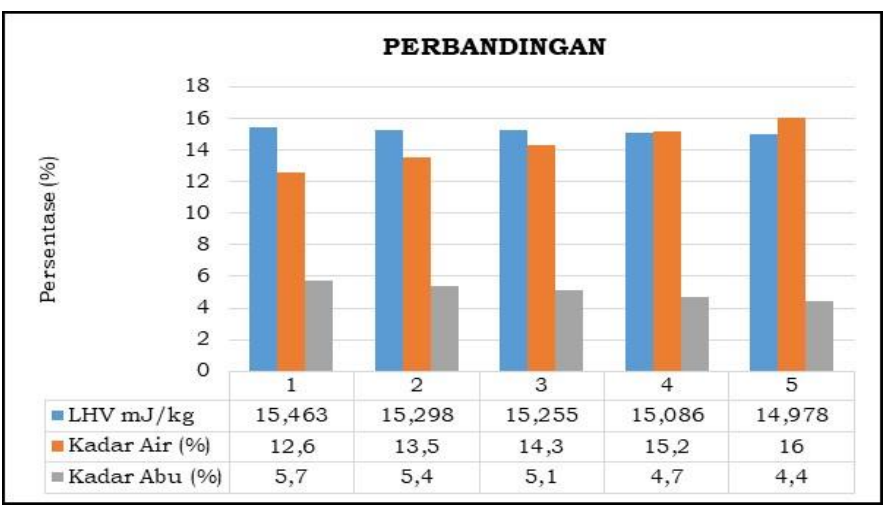

Gambar 8. Perbandingan kadar air dan kadar abu terhadap nilai kalor

Dari grafik di atas diketahui bahwa nilai kalor bahan bakar tertinggi dipengaruhi oleh nilai kadar air dan kadar abu di mana semakin rendah nilai kadar air dan kadar abu bahan bakar akan meningkatkan nilai 
kalor pembakaran. Nilai kalor pembakaran pada variasi komposisi fiber dan cangkang, nilai kalor yang paling tinggi pada bahan 1 yaitu komposisi fiber $100 \%$ dengan nilai kalor $15463,083 \mathrm{~kJ} / \mathrm{kg}$.

\begin{tabular}{clllll}
\hline Parameter & \multicolumn{4}{c}{ Komposisi Bahan Bakar } \\
& $\mathbf{1}$ & $\mathbf{2}$ & $\mathbf{3}$ & $\mathbf{4}$ & $\mathbf{5}$ \\
\hline Kadar Air Terendah & $\sqrt{ }$ & & & \\
Kadar Abu Terendah & & & & & $\sqrt{ }$ \\
Sulfur Terendah & & & & & $\sqrt{ }$ \\
Nilai Kalor Tertinggi & $\sqrt{ }$ & & & \\
Udara Terendah & $\sqrt{ }$ & & \\
Asap Terendah & $\sqrt{ }$ & & \\
\hline
\end{tabular}

Dari tabel 6 dapat dilihat bahwa komposisi terbaik adalah bahan 1 dengan komposisi bahan bakar fiber 100 $\%$. Hal itu dikarenakan beberapa alasan yaitu:

1. Kadar air

Nilai kadar air dari komposisi fiber $100 \%$ adalah nilai terendah dari beberapa variasi komposisi lainnya, yaitu dengan nilai $12,6 \%$. Semakin tinggi nilai kadar air pada bahan bakar akan menyebabkan penurunan mutu bahan bakar karena dapat menurunkan nilai kalor dan memerlukan sejumlah kalor untuk penguapan menurunkan titik nyala, memperlambat proses pembakaran dan menambah volume gas buang.

2. Nilai kalor

Nilai kalor dari komposisi fiber $100 \%$ adalah nilai tertinggi dari beberapa variasi komposisi lainnya, yaitu dengan nilai $15463,083 \mathrm{~kJ} / \mathrm{kg}$. Nilai kalor dipengaruhi oleh nilai kadar air, semakin tinggi kadar air maka semakin rendah pula nilai kalornya.

\section{SIMPULAN}

Hasil penelitian dan analisis dari variasi komposisi fiber dan cangkang yang telah dilakukan dapat disimpulkan bahwa:

1. Nilai kalor dari variasi komposisi fiber dan cangkang berkisar antara 14978,053 kJ/kg-15463,083 kJ/kg. Dengan nilai kalor tertinggi adalah komposisi fiber $100 \%(15463,083 \mathrm{~kJ} / \mathrm{kg})$, dan nilai kalor terendah adalah komposisi cangkang 100\% . (14978,053 kJ/kg)

2. Kebutuhan udara pembakaran dari variasi komposisi fiber dan cangkang berkisar antara $5,342 \mathrm{~kg} / \mathrm{kgBB}-$ $6,359 \mathrm{~kg} / \mathrm{kgBB}$. Kebutuhan udara pembakaran terendah adalah komposisi fiber $100 \%$ dan kebutuhan udara pembakaran tertinggi adalah komposisi cangkang $100 \%$.

3. Komposisi yang memberikan keuntungan tertinggi adalah komposisi fiber 100\%. Dengan rincian nilai kadar air, kebutuhan udara, gas asap dan biaya yang rendah, dan juga menghasilkan nilai kalor yang tinggi.

\section{DAFTAR PUSTAKA}

Angky, P. dan N. I. Supardi, dan A. Suandi. 2016. Analysis Of Fuel Heating Value Of Fibers And Shell Palm oil.

Budi, dan E. 1990. Teknik Pembakaran dasar dan Bahan bakar. Jurusan teknik Mesin Fakultas Teknologi Industri -ITS, Surabaya.

Harris, 2013. Studi pemanfaatan limbah padat dari perkebunan kelapa sawit pada PLTU $6 \mathrm{MW}$ di bangka belitung. Volume 2 .

Muin, S. A. 1988. Pesawat-pesawat konversi energi 1 (Ketel Uap). 1 penyunt. jakarta: rajawali.

Napitupulu, G. R. dan E. Warman. 2014. Studi kelayakan ekonomis PLTU berbahan bakar fiber dan cangkang kelapa sawit sebagai domestic power.

Parinduri, L. 2016. Analisa Pemanfaatan Biomassa Pabrik kelapa Sawit Untuk Sumber Pembangkit Listrik.

Romantua, D., 2007. Kajian Eksperimental Pengaruh Pengurangan Kadar Air Terhadap Nilai Kalor Terhadap Bahan Bakar Padat. Teknik Mesin Universitas Sumatera Utara.

Samlawi, A. K., 2017. Teknik Pembakaran. Banjarbaru: s.n.

Setiawan, Y. 2016. Karakteristik Campuran Cangkang Dan Serabut Buah Kelapa Sawit Terhadap Nilai kalor. 